\title{
CZU:632-78-63 \\ MONITORIZAREA SEZONIERĂ A DĂUNĂTORULUI Heliothis armigera Hbn. LA DIFERITE CULTURI AGRICOLE PRIN APLICAREA CAPCANELOR FEROMONALE
}

\author{
Gheletiuc Olesea, Rusu Iuliana, Nastas Tudor \\ Institutul de Genetică, Fiziologie și Protecție a Plantelor, Chișinău, Republica Moldova \\ e-mail: olesea.gheletiuc@igfpp.md
}

\begin{abstract}
In this article there are presented the results throughout the vegetation period in sunflower and soybean crops with the help of pheromone traps where the development of three generations of $\mathrm{H}$. armigera pest was detected. It was demonstrated that in the sunflower crop were attracted on average about 119.0 males/trap while soybean had an average of about 217 males to a pheromone trap.
\end{abstract}

Key words: Heliothis armigera, pheromones, traps, dispenser, monitoring.

\section{Introducere}

Agricultura ecologică reprezintă un sector de mare perspectivă pentru Republica Moldova, beneficiind de condiţii corespunzătoare pentru dezvoltarea acestui sistem de agricultură, precum solul fertil şi nivelul redus de poluare a spaţiului natural, prin comparaţie cu ţările dezvoltate economic, în care se folosesc pe scară largă tehnologii agricole super intensive, bazate în mare măsură pe îngrăşăminte chimice şi pesticide de sinteză [1].

În ultimul timp, domeniul protecţiei plantelor a făcut progrese importante, marcate prin descoperirea şi aplicare de noi metode moderne în combaterea dăunătorilor, prin diversificarea produselor fitofarmaceutice, utilizarea aparaturii moderne de aplicare şi mai ales prin reconsiderarea întregului sistem de combatere bazat pe o concepţie ecologică, cunoscut sub numele de "Luptă integrală". De asemenea, în schemele de combatere s-au urmărit pe cât a fost posibil înlocuirea pesticidelor toxice, cu produse selective pentru fauna utilă, și aplicarea mijloacelor biologice și biotehnice în vederea evitării poluării mediului precum şi a produselor obținute. Utilizarea feromonilor sexuali, incluși în ultimele două decenii în sistemele de combatere biologică a insectelor dăunătoare, servesc la avertizarea tratamentelor chimice şi stabilirea exactă a ariei de răspândire și la supravegherea nivelului populației a dăunătorilor [2].

Feromonii sexuali a insectelor sunt o componentă indispensabilă a protecției integrate a plantelor. Acestea sunt substanțe ecologice inofensive cu acțiune foarte specifică asupra unui dăunător țintă. Feromonii utilizați în capcane funcționează la norme extrem de mici. Monitorizarea în dinamică sezonieră ne oferă posibilitatea de a marca începutul zborului dăunătorului, zborul în masă, numărul generațiilor, sfârșitul fiecărei generații. La rândul său toate acestea ne ajută la efectuarea unei prognoze corecte şi de se utiliza cele mai eficace metode în lupta cu dăunători, așa cum ar fi și fitofagul Heliothis armigera [3, 4].

Unul din dăunătorii principali a culturilor agricole este buha fructificațiilor (Heliothis armigera), care atacă peste 120 specii de plante dintre care soia, floarea-soarelui, tomatele, porumbul, tutunul, ardeiul, vânăta, fasolea, mazărea, năutul - sunt atacate în cea mai mare măsură. Condițiile climaterice favorabile favorizează dezvoltarea și răspândirea dăunătorului dat. Există unele studii, că precum în condițiile țării noastre se dezvoltă în 2-3 generații pe an [5].

Scopul acestei lucrări a fost de a se efectua monitorizarea în dinamică sezonieră a dăunătorului $H e$ liothis armigera la diferite culturi agricole, folosind capcanele feromonale.

\section{Materiale şi metode}

Experiențele au fost montate pe câmpurile experimentale a Institutului de Genetică, Fiziologie și Protecție a Plantelor. Pentru efectuarea monitorizării dezvoltării populației dăunătorului H. armigera în dinamică sezonieră au fost montate câte 3 capcane feromonale la culturile de floarea-soarelui şi soia. Capcanele au fost repartizate după metoda de şah pe o suprafață de a câte 1 ha. Distanţa dintre capcane era nu mai mică de 70 metri (Fig. 1). 


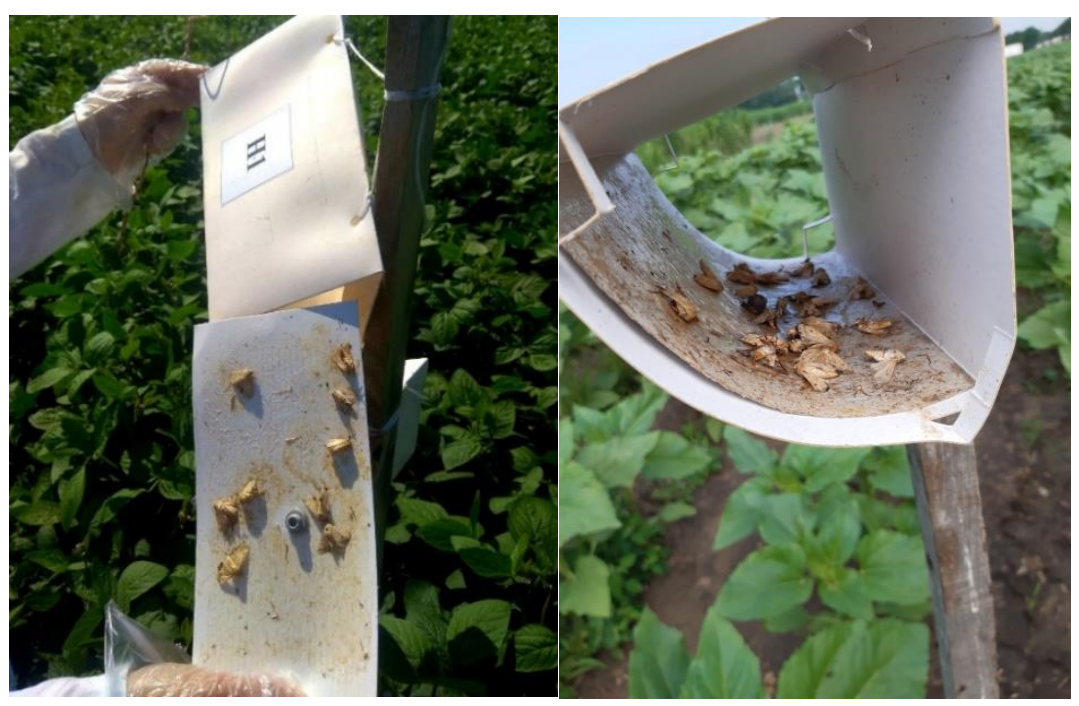

a)

b)

Fig. 1. Repartizarea capcanelor feromonale pe câmpurile experimentale: a) la cultura de soia; b) la cultura de floarea soarelui.

Evidenţa masculilor capturați sa efectuat la fiecare 2 zile. Suporturile adezive, capcanele, și dispensatorii feromonali au fost înlocuiți după necesitate. Rrezultatele obţinute au fost analizate în conformitate cu pachetele software Microsoft.

\section{Rezultate şi discuţii}

Conform rezultatelor ob̧̧inute pe tot parcursul perioadei de vegetaţie la culturile de floarea-soarelui şi soia cu ajutorul capcanelor feromonale au fost fixate dezvoltarea a 3 generaţii a dăunătorului $H$. armigera (Tabelul 1).

Tabelul 1. Aprecierea densității populației dăunătorului Heliothis armigera în dependență de cultura agricolă și generație.

\begin{tabular}{|l|c|c|c|}
\hline \multirow{2}{*}{ Culturile experimentale } & \multicolumn{3}{|c|}{ Numărul masculilor capturați în capcane feromonale/generație } \\
\cline { 2 - 4 } & I & II & III \\
\hline Floarea-soarelui & 161 & 151 & 43 \\
\hline Soia & 127 & 244 & 210 \\
\hline
\end{tabular}

Analiza datelor obținute a demonstrat, că la cultura floarea-soarelui densitatea populației dăunătorului în I generație a fost mai mare în comparație cu cea de la cultura de soia cu circa $21,1 \%$. Tot odată s-a constatat, că în generațiile II și III densitatea populației dăunătorului a fost mai numeroasă la cultura de soia de circa 1,6 ori și 4,9 ori, corespunzător cu densitatea populației la cultura de floarea soarelui. Rezultatele obținute ne-a demonstrat, că cultura de soia este mai preferabilă pentru acest dăunător, comparativ faţă de cultura de floarea soarelui în timpul dezvoltării a generațiilor II și III.

Pe parcursul perioadei de monitorizare sezonieră a densității populației de buha fructificațiilor a fost demonstrat, că la cultura de floarea soarelui au fost atrași în medie circa 119,0 masculi/capcană pe când la cultura de soia au revenit în medie circa 217 masculi la o capcană feromonală. Rezultatele obținute au stat la baza elaborării graficului de activitate sezonieră a acestui dăunător în dependență de fazele fenologice de dezvoltare a culturilor de floarea soarelui și soia (Fig. 2; 3). 


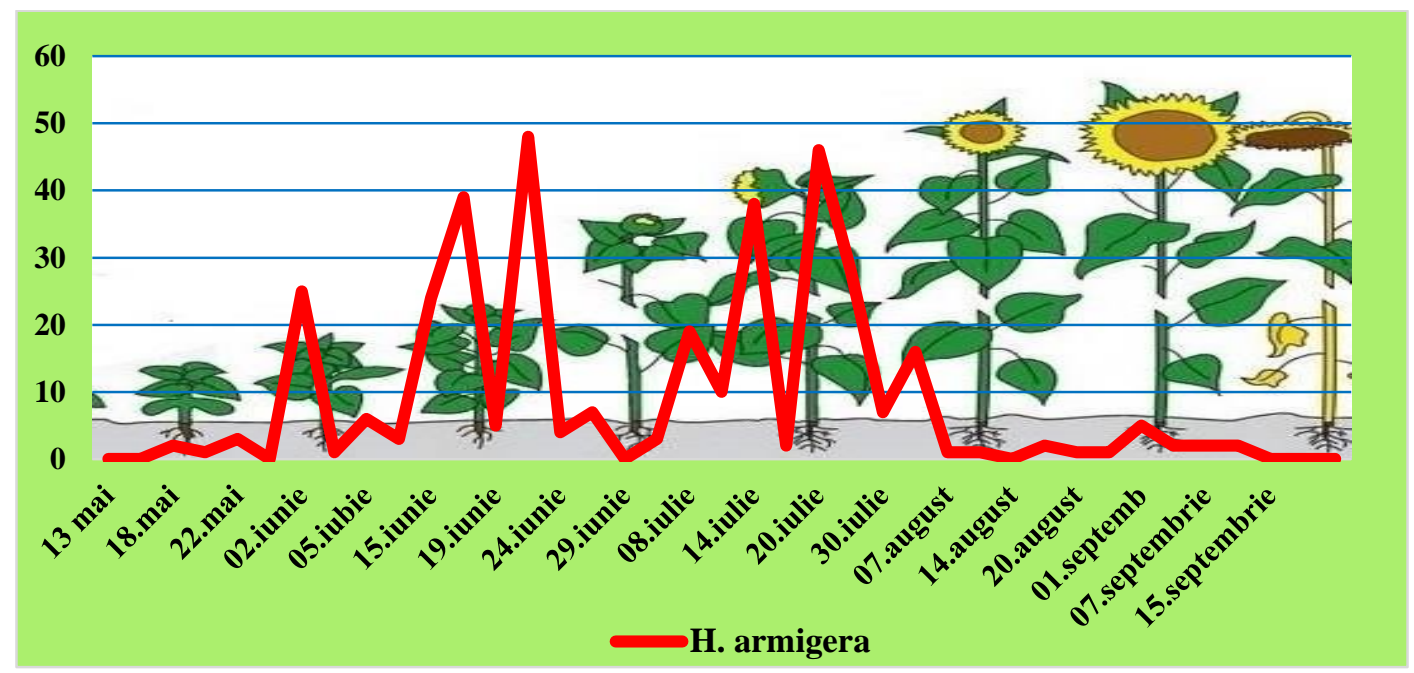

Fig. 2. Monitorizarea sezonieră a activității dăunătorului Heliothis armigera în dependență de fazele fenologice de dezvoltare a culturii de floarea-soarelui.

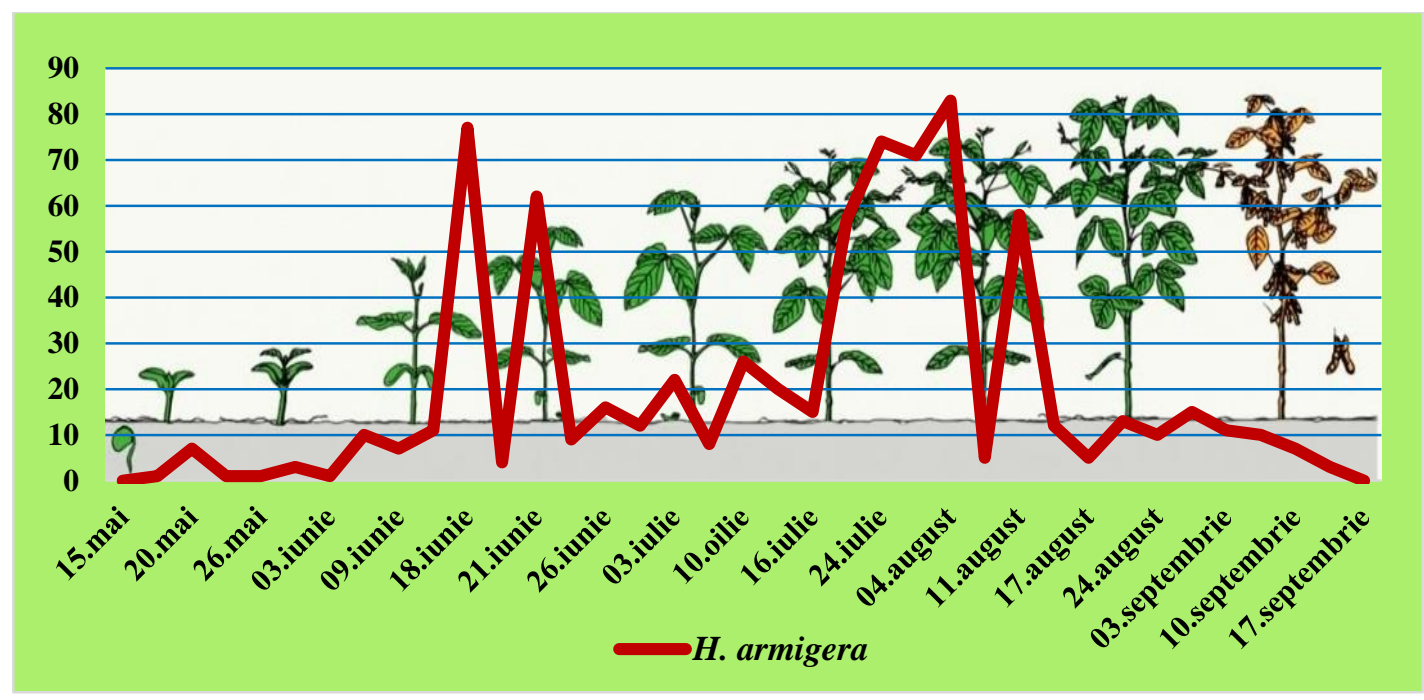

Fig. 3. Monitorizarea sezonieră a activității dăunătorului Heliothis armigera în dependență de fazele fenologice de dezvoltare a culturii de soia.

Monitorizarea în dinamică a activității populației buhei fructificațiilor a demonstrat, că nu au existat deosebiri esenţiale în ce privește durata dezvoltării a trei generaţii la ambele culturi. Astfel, zborul a început în a doua decadă a lunii mai şi a durat până în decada II a lunii septembrie. La soia, prima generaţie a fost observată în prima decată a lunii mai şi a durat până la începutul decadei doi a lunii iunie. A doua generaţie la floarea soarelui şi soia au atins punctul maxim de zbor în masă în a doua decadă a lunii iunie. A treia generaţie la floarea soarelui a atins punctul maxim la sfârşitul decadei doi a lunii iulie iar la cultura de soia - în prima decadă a lunii august.

Din datele obţinute pe tot parcursul perioadei de vegetaţie rezultă că cea mai afectată cultură din cele cercetate este soia.

\section{Concluzii}

1. În rezultatul cercetărilor efectuate s-a constatat că cu ajutorul capcanelor feromonale aplicate la culturile de floarea-soarelui şi soia se poate de monitorizat densitatea populaţiei dăunătorului Heliothis armigera.

2. S-a constatat, că prin aplicarea a minim 3 capcane feromonale/ha se poate de redus numărul de masculi activi din populaţia dăunătorului Heliothis armigera pe tot parcursul perioadei de vegetație. 
Cercetările au fost realizate în cadrul proiectului Programului de Stat 20.80009.5107.27 "Identificarea și evaluarea substanțelor biologic active, a speciilor de entomofagi, culturilor vegetale entomofile, și a mecanismelor interacțiunii acestora în contextul organismelor nocive”, finanțat de Agenția Națională pentru Cercetare și Dezvoltare.

\section{Bibliografie}

1.Agricultura ecologică în Republica Moldova: Perspective locale și regionale, FinAsist Consulting SRL, 2012;

2. ROŞCA, I., OLTEAN, I., MITREA, I., Tratat de Entomologie Generală şi Specială, Buzău, Alpha MDN 2011, pp 6, ISBN 978-973-139-207-3;

3. NASTAS, T. Influenţa feromonilor sexuali asupra mecanismului de reducere a densitătii populațiilor insectelor fitofage. Chişinău: Print - Caro, 2012, p.22-23. ISBN 978-9975-56-039-9;

4. ROŞCA, G., PĂTRAŞCU, T., ODOBESCU, V., NASTAS, T., ELISOVEŢCAIA, D. Eficientizarea formelor preparative a feromonului sexual al buhei fructificaţiilor. Materialele conferinței internaționale ŞtiinţificoPractice „Agricultura Durabilă, inclusiv Ecologică -Realizări, Probleme, Perspective”, Bălți., 2008., p. 152-154;

5. http://www.ansa.gov.md/ro/comunicate/\%C3\%AEn-aten\%C8\%9Bia-agricultorilor-buha-fructifica\%C8\% 9Biilorheliothis-armigera (28.05.2021). 